\title{
Biochemical and Pharmacological Properties of 5-Lipoxygenase Inhibitor KF8940
}

\author{
Shigeto Kitamura, ${ }^{\dagger}$ Kazuko Hashizume, Kenji Ohmori* \\ and Hiroshi KASE \\ Tokyo Research Laboratories, Kyowa Hakko Kogyo Co., Ltd., \\ Machida-shi, Tokyo 194, Japan \\ * Pharmaceutical Research Laboratory, Kyowa Hakko Kogyo Co., Ltd., \\ Nagaizumi-cho, Shizuoka 411, Japan \\ Received July 11, 1988
}

\begin{abstract}
2-n-Heptyl-4-hydroxyquinoline- $N$-oxide (KF8940), isolated from Pseudomonas methanica, was a potent and selective inhibitor of the arachidonate 5-lipoxygenase of rat basophilic leukemia (RBL-1) cells. Kinetic analysis indicated that the inhibitory mode was non competitive. The $K i$ value was $3.5 \times 10^{-7} \mathrm{M}$. KF8940 also inhibited 12-lipoxygenase of bovine platelets in a noncompetitive manner, but with a $K i$ value of $7 \times 10^{-5} \mathrm{M}$. Ionophore A23187-stimulated SRS generation from rat peritoneal cells and antigen-stimulated SRS-A generation from sensitized rat lung were significantly inhibited by KF8940. KF8940 at a dose of $10 \mathrm{mg} / \mathrm{kg}$ (p.o.) suppressed the passive anaphylactic bronchoconstriction in guinea pigs.
\end{abstract}

Biological studies indicate that the cysteinecontaining leukotrienes (leukotriene $\mathrm{C}_{4}, \mathrm{D}_{4}$, and $\mathrm{E}_{4}$ ) and their dihydroxy derivative (leukotriene $\mathrm{B}_{4}$ ) are potent mediators in immediate hypersensitivity reactions as in human asthma or in acute inflammation. ${ }^{1,2)}$ The leukotrienes are synthesized from arachidonic acid, which is released by various stimuli from membrane phospholipids. The first reaction of leukotriene synthesis is oxygenation of arachidonic acid at $\mathrm{C}-5$ by 5 -lipoxygenase to generate 5 HPETE. Therefore, much attention has been focused on 5-lipoxygenase inhibitors as antiasthmatic and anti-inflammatory agents. We have reported that KF8940 (2-heptyl-4-hydroxyquinoline- $N$-oxide), a microbial metabolite, is a potent and selective inhibitor of 5lipoxygenase $\left(\mathrm{IC}_{50}\right.$ was $\left.1.5 \times 10^{-7} \mathrm{M}\right){ }^{3)}$ No inhibitory activities on cyclooxygenase and 12 lipoxygenase were observed at the same order of concentration. In this report, we describe more precise biochemical and pharmacological properties of KF8940.

\section{MATERIALS AND METHODS}

Materials. $\left[1-{ }^{14} \mathrm{C}\right]$ Arachidonic acid $(55.4 \mathrm{mCi} / \mathrm{mmol})$ was purchased from New England Nuclear (Boston). Concanavalin A and calcium ionophore A23187 were obtained from CalBiochem (San Diego), egg white albumin and compound 48/80 were from Sigma (St. Louis), and phosphatidyl-L-serine and nordihydroguaiaretic acid (NDGA) were from Tokyo Kasei (Tokyo). BW-755c was a kind gift from Wellcome Research Laboratories (Beckenham), and disodium cromaglycate (DSCG) was from Fison (London). All other reagents were of analytical grade. The silica-gel precoated TLC plate was obtained from E. Merck (Darmstadt).

Animals and cells. Hartly guinea pigs (male, $400 \sim 500 \mathrm{~g}$ ) and Sprague-Dawley rats (male $250 \sim 300 \mathrm{~g}$ ) were purchased from Shizuoka A. C. A. (Shizuoka). Rat basophilic

* Send correspondence to: S. Kitamura, Pharmaceutical Research Laboratory, Kyowa Hakko Kogyo Co., Ltd. Nagaizumi-cho, Shizuoka, Japan. Tel. 0559-86-7600.

Abbreviations: SRS(-A), slow reacting substance (of anaphylaxis); 5-HETE, 5(S)-hydroxy-6,8,11,14eicosatetraenoic acid; $12(S)$-hydroxy-5,8,10,14-eicosatetraenoic acid; EWA, egg white albumin; DSCG, disodium cromoglycate. 
leukemia (RBL-1) cells [ATCC No. CRL1378] were obtained from the American Type Culture Collection (Rockville).

Measurement of 5-lipoxygenase activity. Preparation of arachidonate 5-lipoxygenase from RBL-1 cells and the activity measurement were described previously. ${ }^{3)}$ Briefly, the cells, grown in Eagle's minimal essential medium with $20 \%$ fetal calf serum, were washed and suspended with phosphate-buffered saline, and stored at $-80^{\circ} \mathrm{C}$ until use. The stored cell suspension was lysed by freeze-thawing just before use, and the homogenate was centrifuged at $10,000 \times g$ for $20 \mathrm{~min}$. The supernatant was used as the enzyme preparation. The standard reaction mixture of 5lipoxygenase contained $0.1 \mathrm{M}$ Tris- $\mathrm{HCl}(\mathrm{pH} 7.4), 1 \mathrm{~mm}$ reduced glutathione, $1 \mathrm{mM} \mathrm{CaCl}_{2}$, and $2 \mathrm{~mm} \mathrm{ATP.} \mathrm{The}$ enzyme $(3.6 \mathrm{mg}$ protein $/ \mathrm{ml})$ was incubated with test samples at $37^{\circ} \mathrm{C}$ for $5 \mathrm{~min}$, and then incubated with $30 \mu \mathrm{M}$ [1$\left.{ }^{14} \mathrm{C}\right]$ arachidonic acid $(1.6 \mu \mathrm{Ci} / \mathrm{ml})$ for $5 \mathrm{~min}$. The reaction mixture was acidified with $0.2 \mathrm{M}$ citric acid ( $\mathrm{PH} \mathrm{3.5)} \mathrm{and}$ the radioactive metabolites were extracted with ethyl acetate. The organic phase was evaporated under an $\mathrm{N}_{2}$ gas stream. The residues were dissolved in ethyl acetate and put on a silica gel TLC plate. Petroleum ether-diethyl ether-acetic acid $(50: 50: 1)$ was used as a developing solvent. The radioactive product, $\left[1-{ }^{14} \mathrm{C}\right] 5$-HETE, was detected by autoradiography, scraped off, and counted in a liquid scintillation counter. The reaction of the 5 lipoxygenase was saturable with respect to arachidonic acid under these conditions, and the $K m$ value for arachidonic acid was $8.1 \times 10^{-5} \mathrm{M}$. The reaction rate was linear at least for $5 \mathrm{~min}$ at the substrate concentration range between 18 and $91 \mu \mathrm{M}$.

Measurement of 12-lipoxygenase activity. Preparation of 12-lipoxygenase from bovine platelet cytosol and measurement of the activity were described previously. ${ }^{4)}$ The standard reaction of 12-lipoxygenase was conducted with the enzyme $(1 \mathrm{mg} / \mathrm{ml})$ in $0.1 \mathrm{M}$ Tris- $\mathrm{HCl}(\mathrm{pH} 7.4), 2 \mathrm{~mm}$ reduced glutathione, and $30 \mu \mathrm{M}\left[1-{ }^{14} \mathrm{C}\right]$ arachidonic acid at $30^{\circ} \mathrm{C}$ for $10 \mathrm{~min}$. The radioactive product, $\left[1-{ }^{14} \mathrm{C}\right] 12-$ HETE, was isolated by TLC using ligroine-diethyl etheracetic acid $(50: 50: 1)$ as the developing solvent, and counted in a liquid scintillation counter. Under these conditions, the reaction rate of 12-lipoxygenase was linear for at least $15 \mathrm{~min}$ at substrate concentrations up to $30 \mu \mathrm{M}$. The reaction was saturable with respect to arachidonic acid, and the $\mathrm{Km}$ value for arachidonic acid was $6.7 \times$ $10^{-5} \mathrm{M}$.

$S R S-A$ generation by sensitized guinea pig lung. Guinea pigs were actively sensitized with an emulsion of $1 \mathrm{mg}$ egg white albumin (EWA) with Freund's complete adjuvant, by the method of Orange and Moore. ${ }^{5)}$ When the serum showed sufficient responses on passive cutaneous anaphylaxis after 3 to 5 weeks, the animals were used for the following experiment. After perfusion of the lung with Tyrode's buffer, lung was excised and minced into $2 \mathrm{~mm}$ fragments. The fragments $(400 \mathrm{mg}$ ) were suspended in $5 \mathrm{ml}$ of Tyrode's buffer and pre-warmed at $37^{\circ} \mathrm{C}$ for $10 \mathrm{~min}$. After the addition of $0.5 \mathrm{ml}$ of drug solution, the suspension was preincubated for another $10 \mathrm{~min}$. The reaction was started by the addition of EWA $(1.67 \mathrm{mg} / \mathrm{ml})$ and incubated for $20 \mathrm{~min}$ with shaking. After filtration with cheese cloth, the reaction mixture was stored at $-80^{\circ} \mathrm{C}$ until bioassay.

SRS generation from rat peritoneal exudate cells. Peritoneal exudate cells, harvested from Sprague-Dawley rats, were suspended at $1 \times 10^{7}$ cells $/ \mathrm{ml}$ in Tyrode's buffer containing $5 \mathrm{~mm}$ reduced glutathione and $5 \mathrm{~mm}$ L-cysteine. The cell suspension was incubated for $5 \mathrm{~min}$ at $37^{\circ} \mathrm{C}$ and the reaction was started by the addition of A23187 $\left(10^{-6} \mathrm{M}\right)$. After $20 \mathrm{~min}$, the reaction mixture was mixed with 4 volume of cold ethanol and left for $1 \mathrm{hr}$ at $0^{\circ} \mathrm{C}$. After centrifugation the supernatant was evaporated to dryness. The residue was dissolved in $70 \%$ methanol, and the SRSA activities were measured.

Measurement of SRS(-A). The SRS(-A) activities were assayed by the biological method of Watanabe-Kohno and Parker. ${ }^{6)}$ Briefly, isolated guinea pig ileum was incubated in an organ-bath with $10 \mathrm{ml}$ of Tyrode's solution containing of $5 \times 10^{-7} \mathrm{M}$ atropine and $1 \times 10^{-6} \mathrm{M}$ tripelennamine. The organ-bath was continuously aerated with $5 \% \mathrm{CO}_{2}$ in air. The contractile response of the ileum was monitored with an isotonic transducer (TD-112S, Nihonkohden, Tokyo).

Measurement of histamine release from rat peritoneal exudate cell. The peritoneal exudate cells were obtained from rats sensitized actively with EWA by the method previously described. ${ }^{7)}$ Histamine was released from the sensitized peritoneal cells by antigen stimulation for $15 \mathrm{~min}$ at $37^{\circ} \mathrm{C}$. Histamine release was also examined using unsensitized peritoneal cells stimulated with $5 \mu \mathrm{g} / \mathrm{ml}$ of compound $48 / 80$ for $15 \mathrm{~min}$ at $37^{\circ} \mathrm{C}$. Histamine was measured by the fluorometric method of Shore et al. ${ }^{8 \text { ) }}$ Drugs tested were incubated with the cells for $10 \mathrm{~min}$ before induction of histamine release.

Experimental allergic asthma in guinea pigs. The inhibitory effect of KF8940 on passive anaphylactic bronchoconstriction in guinea pigs sensitized with anti-EWA rabbit serum was examined as described previously. ${ }^{9}$ KF8940 was administrated orally $1 \mathrm{hr}$ before antigen challenge. The sensitized animals were anesthetized with urethane $(1.2 \mathrm{~g} / \mathrm{kg}$, i.p.) and stopped the spontaneous respiration by gallamine triethiodide $(10 \mathrm{mg} / \mathrm{kg}, i . v$.). The anaphylactic bronchoconstriction, induced with EWA $(1 \mathrm{mg} / \mathrm{kg}, i . y$ ), was monitored as air overflow volume by a modified method of Konzett and Rössler. ${ }^{10}$

Preparation of rat liver mitochondria. Mitochondria were prepared by the method of Johnson and Lardy. ${ }^{11)}$ 
Liver of rat was minced and homogenized with a Teflon homogenizer $(0.15 \sim 0.2 \mathrm{~mm}$ pestle clearance) in $0.25 \mathrm{M}$ sucrose-Tris buffer ( $\mathrm{pH} 7.4$ ). The homogenate was layered on $0.35 \mathrm{~m}$ sucrose-Tris buffer $(\mathrm{pH} 7.4)$ and centrifuged at $700 \times g$ for $10 \mathrm{~min}$ vertically. The $0.25 \mathrm{M}$ sucrose layer was centrifuged again at $7000 \times g$ for $10 \mathrm{~min}$. The precipitate, resuspended with $0.25 \mathrm{M}$ sucrose-Tris buffer $(28 \mathrm{mg}$ protein $/ \mathrm{ml}$ ), was used as the mitochondrial solution.

Oxygen consumption assay. Oxygen consumption was monitored using a oxygraph equipped with a Clark oxygen electrode by the method of Howland. ${ }^{12)}$ The reaction was done in $50 \mathrm{~mm}$ Tris- $\mathrm{HCl}$ buffer ( $\mathrm{pH} 7.4$ ) containing $15 \mathrm{~mm} \mathrm{KCl,} 2 \mathrm{~mm}$ EDTA, $5 \mathrm{~mm}^{\mathrm{mgCl}_{2}}, 12.5 \mathrm{~mm}$ phosphate, $50 \mathrm{~mm}$ succinate, and $1.4 \mathrm{mg}$ of rat liver mitochondria.

\section{RESULTS}

The mode of inhibition of 5-lipoxygenase by KF 8940

$\mathrm{KF} 8940$ from $\mathrm{I} \times 10^{-7} \mathrm{M}$ to $1 \times 10^{-6} \mathrm{M}$ was

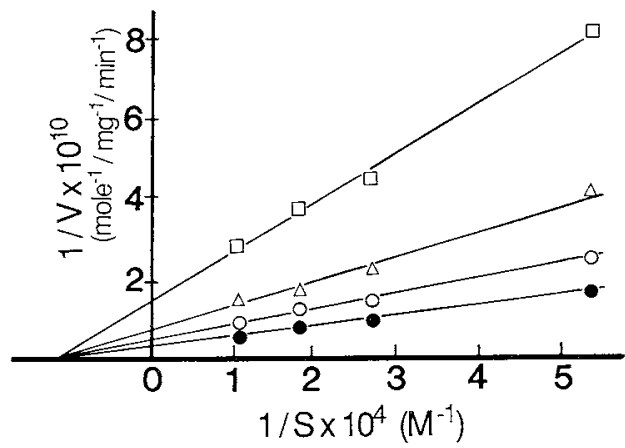

a

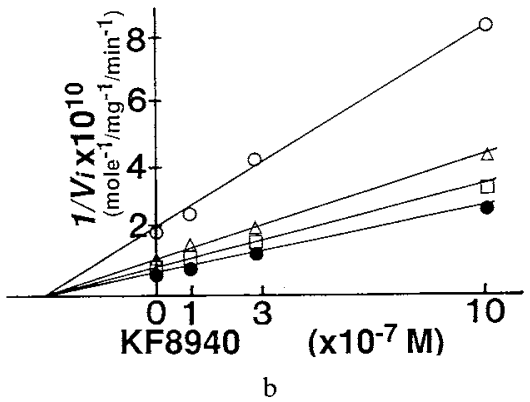

FIG. 1. Inhibition of 5-Lipoxygenase by KF8940.

RBL-1 5-lipoxygenase was assayed at several substrate concentrations as described in MATERIALS AND METHODS. a: Lineweaver-Burk plot at various concentrations of KF8940. $0.0 \mathrm{M}(\bigcirc), 10^{-7} \mathrm{M}(\mathrm{O}), 3 \times 10^{-7} \mathrm{M}(\triangle), 10^{-6} \mathrm{M}$ ( $\square$ ). b: Dixon plot at various concentrations of arachidonic acid. $18.3 \mu \mathrm{M}(\bigcirc), 36.7 \mu \mathrm{M}(\triangle), 55.1 \mu \mathrm{M}(\square), 91.9 \mu \mathrm{M}$ (O). incubated with 5-lipoxygenase at varying concentrations of arachidonic acid. LineweaverBurk plots (Fig. 1a) show that KF8940 inhibits 5-lipoxygenase in a non-competitive manner. The $K i$ value estimated from Dixon plots (Fig. 1b) was $3.5 \times 10^{-7} \mathrm{M}$. At higher concentrations, KF8940 also inhibited 12-lipoxygenase non-competitively, and the $K i$ value was $6 \times$ $10^{-5}$ M (Fig. 2a, b).

\section{Effects of Anti-Respiratory Drugs on 5-lipoxy- genase}

Since KF8940 is an inhibitor of the respiratory chain, ${ }^{12)}$ other typical anti-respiratory agents (antimycin $\mathrm{A}, \mathrm{KCN}$, and $\mathrm{NaN}_{3}$ ) were tested for lipoxygenase inhibition. Table I summarizes the inhibitory activities of these agents on 5-lipoxygenase comparing with their effects on rat liver mitochondrial oxygen up-
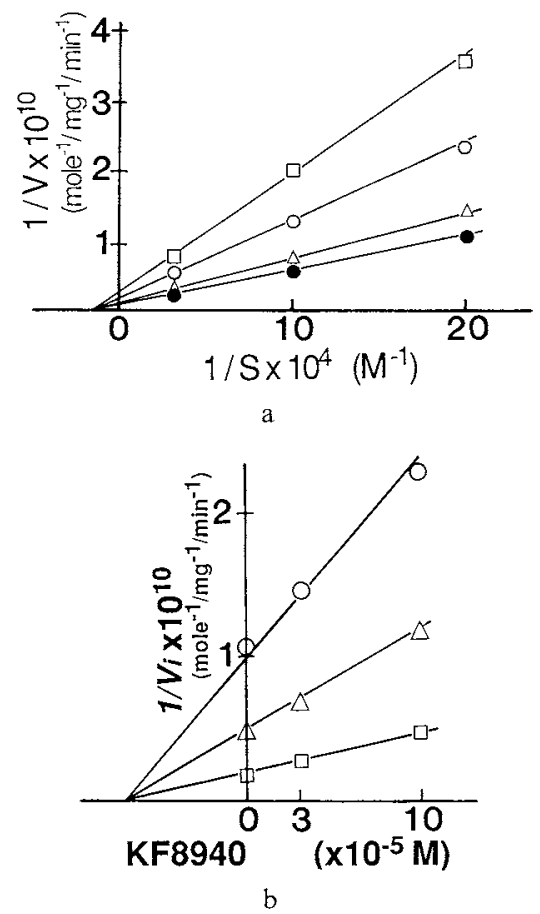

FIG. 2. Inhibition of 12-Lipoxygenase by KF8940.

Bovine platelet 12-lipoxygenase was assayed at several substrate concentrations as described in MATERIALS AND METhods. a: Lineweaver-Burk plot at various concentrations of $\mathrm{KF} 8940.0 .0 \mathrm{M}(\odot), 3 \times 10^{-5} \mathrm{M}(\triangle), 10^{-4} \mathrm{M}$ (O), $3 \times 10^{-4} \mathrm{M}(\square)$. b: Dixon plot at various concentrations of arachidonic acid. $5.0 \mu \mathrm{M}(\bigcirc), 10.0 \mu \mathrm{M}(\triangle)$, $30.0 \mu \mathrm{M}(\square)$. 
take. KF8940 inhibited both reactions to a similar degree. Antimycin A also inhibited 5lipoxygenase. But the inhibitory activity on 5 lipoxygenase $\left(\mathrm{IC}_{50}: 2.6 \times 10^{-4} \mathrm{M}\right)$ was three orders of magnitude less potent than that of

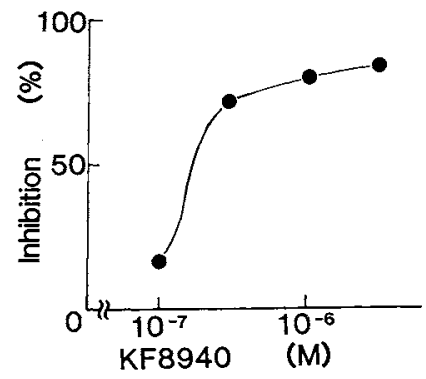

a

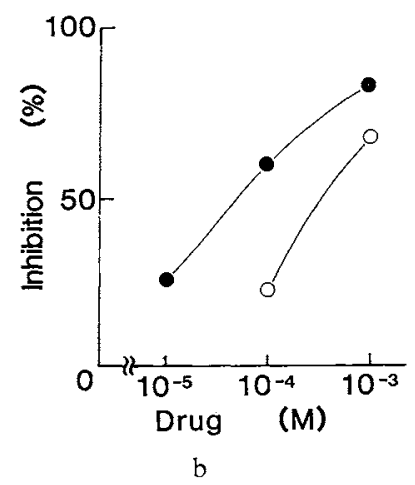

F1G. 3. Effects of KF8940 on SRS-A Generation.

a: SRS generation from A23187 stimulated rat peritoneal exudate cells. b: SRS-A generation from lung of actively sensitized guinea pig. KF8940 (O), BW-755c (O). Each point represents the percentage of inhibition calculated by the mean of $3 \sim 5$ experiments.
KF8940 and four orders of magnitude less potent than the antirespiratory activity. $\mathrm{KCN}$ and $\mathrm{NaN}_{3}$ showed no inhibition of 5-lipoxygenase even at $10^{-3} \mathrm{M}$. Thus, no correlation between 5-lipoxygenase inhibition and anti-respiratory activity was observed.

\section{Effects on SRS-A generation}

The effects of KF8940 on the generation of SRS (-A) from rat peritoneal exudate cells and from sensitized guinea pig lung were examined. The SRS generation from rat peritoneal exudate cells stimulated with the calcium ionophore A23187 was completely inhibited by $10^{-6} \mathrm{M}$ the $\mathrm{KF} 8940$ and the $\mathrm{IC}_{50}$ was $2 \times$ $10^{-7} \mathrm{M}$ (Fig. 3a). SRS-A generation from sensitized guinea pig lung stimulated with antigen

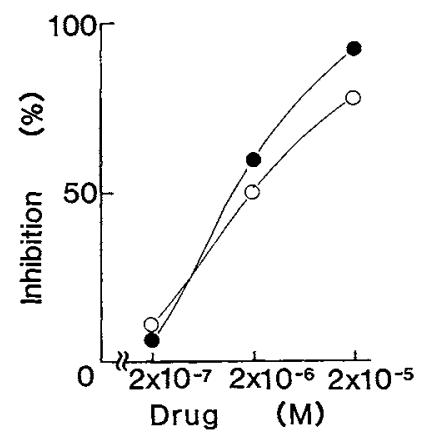

FIG. 4. Effects of KF8940 on Histamine Release from Actively Sensitized Rat Peritoneal Exudate Cells. KF8940 (O), DSCG (O). Each point represents the percentage of inhibition calculated by the mean of $3 \sim 5$ experiments.

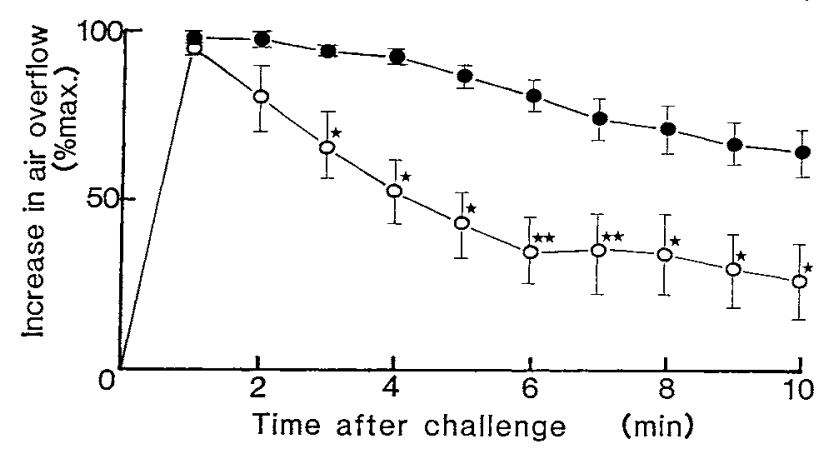

FIG. 5. Effects of KF8940 on Anaphylactic Bronchoconstriction in Passively Sensitized Guinea Pigs. Statistical significance $(p<0.5)$ was observed from $3 \mathrm{~min}$ after elicitation of bronchoconstriction. Control ( () ), $n=18 . \mathrm{KF} 8940(0), 10 \mathrm{mg} / \mathrm{kg}, p . o ., n=6 . \star, \star \star$ : Significantly different from the control at $p<0.5$ and $p<0.05$, respectively. 
was also inhibited by $\mathrm{KF} 8940$ with the $\mathrm{IC}_{50}$ value of $8 \times 10^{-5} \mathrm{M}$. The inhibitory activity was stronger than that the of known lipoxygenase inhibitor BW-755c (Fig. 3b).

\section{Suppression of histamine release}

The suppressions of the histamine release from passively sensitized rat peritoneal exudate cells by KF8940 and DSCG were observed. The histamine release was completely suppressed by $2 \times 10^{-5} \mathrm{M}$ of $\mathrm{KF} 8940$ and the $\mathrm{IC}_{50}$ value was $1.8 \times 10^{-6} \mathrm{M}$. The inhibitory activity was nearly equal to that of DSCG, which is a potent suppresser of histamine release from rat mast cells ${ }^{7)}$ (Fig. 4).

\section{Effects on anaphylactic bronchoconstriction in guinea pig}

Pharmacological activities of KF8940 in vivo were examined in experimental allergic asthma in guinea pigs. EWA challenge resulted in an anaphylactic bronchoconstriction to $98 \%$ of the maximum in control animals. When animals were given KF8940 orally $(10 \mathrm{mg} / \mathrm{kg}) 1 \mathrm{hr}$ before the antigen challenge, the bronchoconstriction was significantly reduced as shown in Fig. 5. No acute toxicity was observed at $400 \mathrm{mg} / \mathrm{kg}$ orally in rats.

\section{DISCUSSION}

The kinetic analysis of the inhibition of 5and 12-lipoxygenase by KF8940 indicates that the compound is a non-competitive inhibitor of both enzymes. The $K i$ value for 5-lipoxygenase was two orders of magnitude lower than that for 12-lipoxygenase, indicating its high selectivity for 5-lipoxygenase.

KF8940 inhibited the formation of SRS (mixture of leukotriene $\mathrm{C}_{4}, \mathrm{D}_{4}$ and $\mathrm{E}_{4}$ ) from endogenous arachidonic acid stimulated by A23187 in rat peritoneal exudate cells. Antigen-induced SRS-A formation by the lung tissue fragments of sensitized guinea pig was also significantly inhibited by KF8940. AhnfeltRønne and Olsen reported that leukotriene production in rat peritoneal leukocytes was inhibited by compounds known to interfere
TABLE I. INHIBITION OF 5-LIPOXYGENASE AND OXygen UPTaKe IN Rat Liver MitochondRia By KF8940 and TyPiCAL ANTIRESPIRATORY DRUGS

\begin{tabular}{lcc}
\hline \multirow{2}{*}{ Compounds } & \multicolumn{2}{c}{$\mathrm{IC}_{50}(\mathrm{M})$} \\
\cline { 2 - 3 } & 5-Lipoxygenase & Oxygen uptake \\
\hline $\mathrm{KF8940}$ & $1.5 \times 10^{-7}$ & $1.2 \times 10^{-7}$ \\
Antimycin A & $2.6 \times 10^{-4}$ & $1.0 \times 10^{-8}$ \\
$\mathrm{KCN}_{\mathrm{NaN}}$ & $\mathrm{NI}\left(\right.$ at $\left.10^{-3}\right)$ & $5.0 \times 10^{-7}$ \\
& $\mathrm{NI}\left(\right.$ at $\left.10^{-3}\right)$ & $6.0 \times 10^{-6}$ \\
\hline
\end{tabular}

The $10,000 \times g$ supernatant of RBL- 1 homogenate was used as 5-lipoxygenase, and rat liver mitochondria was used for oxygen uptake as described in MATERIALS AND METHODS. The results were expressed as the half-maximal inhibition $\left(\mathrm{IC}_{50}\right)$. NI denotes no inhibition.

with normal ATP synthesis such as antimycin A. ${ }^{13)}$ KF8940 was reported as an inhibitor of electron transport between the cytochrome $b$ and $c$ segments of the respiratory chain. ${ }^{143}$ Actually, KF8940 inhibited oxygen uptake of rat liver mitochondria at the same concentration range as 5-lipoxygenase inhibition. The inhibitory activity of KF8940 on oxygen uptake was weaker than that of antimycin $\mathrm{A}$ but stronger than other typical anti-respiratory agents (Table I). However, antimycin A and other anti-respiratory agents (potassium cyanide and sodium azide) showed weak or no inhibitory activities on 5-lipoxygenase. Therefore, as suggested by Ahnfelt-Rønne and Olsen, ${ }^{13)}$ the inhibition of the leukotriene production in intact cells by antirespiratory agents (such as antimycin A) appears not to be due to the direct action on 5-lipoxygenase, but to some other indirect effects. In contrast, the inhibitory activity on SRS formation by KF8940 seems not to be deduced from its anti-respiratory activity, since the preliminary data showed that in intact cells, KF8940 hardly affected the oxygen uptake at the concentrations inhibiting SRS biosynthesis. Furthermore, the $\mathrm{IC}_{50}$ for SRS generation $\left(2 \times 10^{-7} \mathrm{M}\right)$ in rat peritoneal exudate cells was in good accordance with the value for 5-lipoxygenase $\left(1.5 \times 10^{-7} \mathrm{M}\right)$. Taken together, we concluded that the 5-lipoxygenase inhibi- 
tion by KF8940 resulted in inhibition of the SRS biosynthesis in peritoneal exudate cells and the anti-respiratory action of the compound seems to hardly contribute to the inhibition of SRS formation.

KF8940 inhibited histamine release from passively sensitized rat peritoneal exudate cells. Several 5-lipoxygenase inhibitors, and anti-respiratory agents were reported to inhibit histamine release. ${ }^{15,16)}$ However, the precise mechanism of the inhibition of histamine release by KF8940 is not known.

KF8940 significantly suppressed the antigen-induced bronchoconstriction of guinea pigs. Inhibitory activity of KF8940 in SRS-A formation seemed to contribute, at least to some extent, to the suppressive effects in this in vivo model. The possibility that the suppression of histamine release may contribute to the inhibitory action might also be taken into consideration.

Acknowledgment. We thank to Miss M. Kaneko for her technical assistance.

\section{REFERENCES}

1) B. Samuelsson, in "Advances in Prostaglandin, Thromboxane, and Leukotriene Research," Vol. 11, ed. by B. Samuelsson et al., Raven Press, New York, 1983, pp. $1 \sim 13$.

2) B. Samuelsson, Science, 220, 568 (1983).

3) S. Kitamura, K. Hashizume, T. Iida, E. Miyashita, K. Shirahata and H. Kase, J. Antibiot., 39, 1160 (1986).

4) S. Kitamura, T. Iida, K. Shirahata and H. Kase, $J$. Antibiot., 39, 589 (1986).

5) R. P. Orange and E. G. Moore, J. Immunol., 116, 392 (1979).

6) S. Watanabe-Kohno and C. W. Parker, J. Immunol., 125, 946 (1980).

7) K. Ohmori, H. Ishii, K. Shuto and N. Nakamizo, Folia Pharmacol. Japon., 80, 441 (1982).

8) P. A. Shore, A. Burkhalter and V. H. Cohn, $J$. Pharmacol. Exp. Ther., 127, 182 (1959).

9) K. Ohmori, H. Ishii, Y. Takei, K. Shuto and N. Nakamizo, Folia Pharmacol. Japon., 80, 481 (1982).

10) H. Konzett and R. Rössler, Naunyn-Schmiedeberg's. Arch. Exp. Path. Pharmak., 195, 71 (1940).

11) D. Johnson and H. Lardy, in "Methods in Enzymology," Vol. 10, ed. by R. W. Estabrook and M. E. Pullman, Academic Press, New York, 1967, pp. $94 \sim 96$.

12) J. L. Howland, Biochim. Biophys. Acta, 73, 665 (1963).

13) I. Ahnfelt-Rønne and U. B. Olsen, Biochem. Pharmacol., 34, 3095 (1985).

14) J. W. Lightbown and F. L. Jackson, Biochem. J., 63, 130 (1956).

15) A. M. Magro, J. Immunopharm., 4, 15 (1982).

16) H. Moussatche and A. Prouvost-Danon, Biochem. Pharmacol., 11, 603 (1982). 